\title{
Singing its Way to Prosperity: Shaping the Public Mind through "Healthy Popular Music" in South Korea
}

\author{
JUNG MIN MINA LEE
}

\begin{abstract}
After seizing power in 1961, South Korea's Park Chung-Hee imposed cultural policies to mediate Korean people's everyday consumption of popular culture. For instance, a certain group of songs was banned for reasons such as crude vocalization and vulgar or dangerous lyrics, while a new type of song, called kŏnchon kungmin kayo, emerged under the government's auspices. Translated as "healthy popular song," kŏnchon kungmin kayo reflected the goals of the Park regime, such as modernization, self-reliance, and economic betterment. Throughout the 1960s, the Bureau of Public Information and the Supreme Council for National Reconstruction launched nationwide calls for songs to engage everyday Koreans in the creation of kŏnchon kungmin kayo, which was then distributed through a series of community singing campaigns named "Echoes of songs." By investigating the modes of creation, dissemination, and consumption of kŏnchon kungmin kayo and examining select songs closely, this essay reveals that the Park government promoted kŏnchon kungmin kayo mainly by encouraging civilian participation during the 1960s, drawing a clear distinction to the punitive enforcement and regulation of popular music after the enactment of the Yusin constitution in 1972. This essay further suggests that, because the initial development of kŏnchon kungmin kayowas gradual and civilian-oriented, the implementation ofkŏnchon kungmin kayowas doctrinaire but also effective in increasing the morale of Koreans during the pre-Yusin Park era.
\end{abstract}

\section{Introduction}

In 1960s South Korea, there was a newly strengthened interest in establishing a collective national identity. In fact, achieving a strong, unified national identity and sovereignty had been on the minds of Koreans since the end of the nineteenth century, when various foreign forces-including China, Russia, Japan, America, France, Germany, and the United Kingdom—sought to exert influence over the Korean peninsula. The goal of establishing a powerful national identity was only reinforced through the ensuing colonization by Japan (1910-1945) and the US military government's trusteeship of Korea after the liberation. When the 1960s dawned, however, the prevailing notion of confirming a national identity began to merge with the new rhetoric of "self-reliance," and public calls to modernize society gained fresh impetus. As will be shown below, such phenomena coincided with significant changes in Korea's sociopolitical milieu, both domestic and international. Internally, the new regime of Park Chung-Hee, who came into power in 1961, emphasized with an unprecedented urgency the need for Korea's economic betterment above any other social issues. Externally, he pushed for Korea's normalization of relations with 
Japan, participation in the Vietnam War, and increasing economic exchanges with countries other than the US. ${ }^{1}$

These social and political transformations came hand in hand with Park's attempts to change the lifestyles of Koreans in fundamental ways. One way to foster such transformation was through cultural policies that promoted the ideals of modernized society and self-reliance. On one level, the government initiated various campaigns and rules to lay the groundwork to reshape Korea's cultural landscape; the measures included establishing new laws regarding media, films, and recordings as well as various projects to restore and protect Korea's cultural heritage. On another level, the government policed Korea's popular culture both with a sweeping stroke and in scrupulous details, and regulating popular music was at the center of Park regime's cultural policies. A significant part of that regulation comprised implementing new standards for popular music, which eventually led to a ban on a large number of well-loved songs. At the same time, the government launched various campaigns to create and disseminate a new type of popular song, kŏnchŏn kungmin kayo, translated as "healthy national popular songs," whose lyrics and musical style aligned with the regime's policies.

This essay is a study of kŏnchŏn kungmin kayo of the 1960s. The essay has four objectives: (1) it investigates the sociocultural changes during the first decade of the Park government that gave rise to the cultural category of kŏnchŏn kungmin kayo, which became a major popular music genre by the following decade; (2) it introduces and analyzes select songs identified as kŏnchŏn kungmin kayo, focusing on their lyrics and musical characteristics and inquiring how they reflect the Park regime's governing philosophy; (3) it examines the ways the songs were distributed; and (4) and finally, it asks, and attempts to answer, how influential these songs were in shaping the minds of Korean people at the time. Historical newspapers, interviews, and accounts of Korean citizens (including my own relatives) who lived through that era offer a glimpse into the soundscape of that period and the songs' role in Korean people's daily lives.

Before delving into kŏnchŏn kungmin kayo of the 1960s, it may be worthwhile to consider comparable notions from the previous decades. Although similar labels were used prior to the 1960s, different meanings were attached to them at various times. During the Japanese colonial era, especially in the late 1930s, kŏnchŏn kayo (translated as "healthy popular songs" or "moral popular songs") indicated songs that transpired as a result of the Song Purification Movement, or kayo chŏnghwa undong, initiated by the Japanese Governor-General of Korea. Also referred to as kajŏng kayo ("popular music for homes"), kŏnchŏn kungmin kayo of the 1930s designated songs that were in accord with imperial Japan's governing principles or its war ideologies. ${ }^{2}$ Around 1953, just after the end of the Korean War, the term kungmin kayo ("national popular music" or "popular music of the people") surfaced prominently in public discourse, appearing in newspapers or used as radio program titles. These songs emerged as concerns toward increasing influences of "immoral" Western popular music and lingering traces of Japanese popular music were intensifying. ${ }^{3}$ Kungmin kayo songs of the post-Korean War era were often bluntly patriotic in their message and mostly march-like, a far cry from what today's popular music sounds like. For instance,

\footnotetext{
${ }^{1}$ Political scientist Byung-Kook Kim assesses that Park "dexterously brought the United States and Japan into a transnational coalition in support of his program of economic growth and military build-up." Byung-Kook Kim, "Introduction: The Case for Political History," in The Park Chung-Hee Era: The Transformation of South Korea, ed. ByungKook Kim and Ezra F. Vogel (Cambridge, MA: Harvard University Press, 2011), 5, https://doi.org/10.4159/harvard.9780674061064.intro.

${ }^{2}$ See Michael Robinson, "Broadcasting, Cultural Hegemony, and Colonial Modernity, 1924-1945" in Colonial Modernity in Korea, ed. Shin Gi-Wook and Michael Robinson (Cambridge, MA: Harvard University Asia Center, 1999), 52-69. ${ }^{3}$ Dong-a Ilbo, June 13, 1954, 4. Also, in August 1953, it was announced that all the Japanese recordings were confiscated from households by the government. Kyunghyang Shinmun, August 6, 1953, 2.
} 
a war survivor's interview reveals that kungmin kayo of the late 1950s included Korea's national anthem and the popular folk song "Arirang." In addition, public discussions on the state of music of the time indicate that the term kungmin kayo also referred to a certain social and moral goal for South Korea's popular music: some ideal type of popular music yet to be realized, a kind that could be loved and enjoyed by the public and minimally influenced by foreign trends. Kŏ nchŏn kungmin kayo of the Park regime was clearly distinguishable from these similarly named genres of the earlier periods, whether in origination, message, or style. Created under the government's supervision and distributed to the public strategically, kŏnchŏn kungmin kayo during the Park Chung-Hee regime was essentially propaganda music, carrying messages that agreed with his governing ideals.

The regulation of popular music in post-colonial South Korea has been investigated with a sense of urgency by historians, music critics, and cultural scholars alike. ${ }^{5}$ Yet, most studies have centered on the 1970s and 1980s when the censorship was at its most intense. In October 1972, Park introduced the Yusin [new government] Constitution, enacting the new constitution that allowed him an unlimited governing power and the possibility of lifetime presidency. ${ }^{6}$ Also established in that same year was the new law to promote culture and art (Munhwa Yesul Chinhŭngbŏp), which stated that the government would take active measures to "protect and promote" arts and culture rather than leaving the task in the hands of the general public. Consequently, a committee to oversee cultural events under direct control of the prime minister emerged. ${ }^{7}$ From this point until 1987-the end of the presidency of Park's successor Chun DooHwan-saw the most severe policing of the press and media in post-liberation Korea. Whereas scholars have given this time much-deserved critical attention, the 1960s has received relatively little consideration, often being mentioned as a backdrop to the Yusin period.

The reason for the disinterest in the 1960s is twofold. First, the regulation of popular songs before the Yusin rule was comparatively lenient. For example, records show that throughout 1966, there were at least 132 instances where a "prohibited" song was played on the Korean Broadcasting System, South Korea's national network. ${ }^{8}$ Moreover, in the 1960s, songs were banned chiefly because they plagiarized Japanese popular songs, were composed by musicians who defected to North Korea, or had vulgar qualities, however that was determined. ${ }^{9}$ After the promulgation of Yusin in 1972, however, not only did the policing of popular songs escalate, but the reasons for banning certain songs directly reflected the authoritarian nature of the Park regime: even the slightest hint of conflicting with Park's governing ideals rendered a song "unhealthy." The reasons for banning a song during this time included presenting a threat to national security; blind adoption of foreign musical styles; conveying spirits of defeat, self-torment, and

\footnotetext{
${ }^{4}$ Dong-a Ilbo, September 19, 1958, 3.

${ }^{5}$ Yŏng-mi Yi, Han'guk Taejung Kayosa [History of Korean Popular Music] (Seoul: Minsogwŏn, 2006), 221-296; Song Hwasuk, "Pahk Ch’ŏng-Hŭi ǔi Kukka Kŭndehwa Pŭrojektŭ wa Ŭmak” [Park Chung-Hee's national modernization project and music], Ǔmak-sa Yŏnku [Music History Studies] 1 (2012): 167-204.

${ }^{6}$ For the details and consequences of the Yusin Constitution, see Youngju Ryu, ed., Cultures of Yusin: South Korea in the 1970s (Ann Arbor: University of Michigan Press, 2018), https://doi.org/10.3998/mpub.9709426.

${ }^{7}$ A similar organization, Han'guk Yesul Munhwa Yulli Wiwŏnhoe [Korean arts and culture ethics committee], had been formed in 1966; in 1975, after the declaration of the Yusin, that committee was transformed into Han'guk Kongyŏn Yulli Wiwŏnhoe

[Korean performance ethics committee].

${ }^{8}$ Kyunghyang Shinmun, December 28, 1966, 5.

${ }^{9}$ These bans were lifted in 1987 and 1988.
} 
sorrow; and having degenerate, "decadent" qualities. ${ }^{10}$ The severity of the Yusin laws, as well as the overall austerity of the period, has made the 1970s and the 1980s synonymous with cultural oppression, far more distinctly than the 1960s.

Second, during the 1960s, kŏnchŏn kungmin kayo was sung mostly by the general public, although professional singers and government leaders were often in the position to lead. In comparison, in the following two decades, it was promoted through largely mandatory performances by professional singers in addition to public singing. In fact, by 1979, the South Korean government imposed a law that required musicians to include a kŏnchŏn kungmin kayo song in every album. For the musicians whose careers took place during the 1970s and 1980s, the combination of being silenced-having their music banned-and being forced to sing propaganda songs made the Yusin era one of the darkest times in post-colonial Korea. Those musicians' experiences have been documented and analyzed considerably in academic, journalistic, and popular literature since the revision of South Korea's constitution in 1987. ${ }^{11}$ Furthermore, many studies have centered on banned songs, as well as the practice of banning songs, rather than kŏnchŏn kungmin kayo because of the former's greater musical value as well as the scholarly significance of uncovering previously unheard music. ${ }^{12}$ Such studies have been invaluable in revealing the nature of the banned songs and the directions South Korean popular music would have taken had there been no government intervention. At the same time, discussions of the policing of popular music and the kŏnchŏn kungmin kayo practice of the 1960s have been relegated to secondary importance compared to the fullfledged crackdown on popular culture of the later decades.

Focusing on kŏnchŏn kungmin kayo of the 1960s, this essay examines the less explored aspect of popular music culture during the Park Chung-Hee era. ${ }^{13}$ Furthermore, by so doing, it reveals that there was a progression in the kŏnchŏn kungmin kayo practice, developing from mostly civil engagements to the more pervasive and invasive custom of the Yusin period. That is, the efforts to "purify" popular music were always initiated by the government, reflecting Park's objectives of cultivating a moral sound world, yet they began with attempts to foster voluntary participation of civilians before turning into a compulsory practice in the 1970s. Finally, it should be noted that significant research has been done on the political

\footnotetext{
${ }^{10}$ Numerous songs disappeared from the public radar, being considered to have violated one of the categories. For instance, songs banned for the reason of "being a threat to national security" included the singer-songwriter Han Dae-soo's "Mul chom chuso" [Give me some water] (1974) and "Haengbogŭi nararo" [To the land of happiness] (1974); the former was accused of evoking water torture, and the latter was condemned for suggesting that Korea was not a happy country under Park ChungHee. These songs can be heard here: "Mul chom chuso" [Give me some water], https://www.youtube.com/watch?v=m3z0HJirgQI; "Haengbogŭi nararo" [To the land of happiness], https://www.youtube.com/watch?v=7AgBcabdplM.

${ }^{11}$ While most of these writings are in Korean, Park Chung-Hee's crackdown on popular music has been accounted in Western media as well. See Stevie Chick, "Shin Joong Hyun: South Korea’s Psychedelic Mimic Turned Master," The Guardian, September 15, 2011, https:/www.theguardian.com/music/2011/sep/15/shin-joong-hyun-korean-psychedelic; Anon., "South Korea Banning 'Decadent' Foreign Music, Including Many Protest Songs,” The New York Times, December 28, 1975, https:/www.nytimes.com/1975/12/28/archives/south-korea-banning-decadent-foreign-music-including-manyprotest.html.

${ }^{12}$ Ok-pae Mun, Han'guk Kŭmjigok ŭi Sahoesa [Social history of banned songs in Korea] (Seoul: Yesol, 2004); Kim Eun-kyoung, "Yusin Cheje ŭi Ǔmak Tongje Yangsange Kwanhan Yŏnku: Kŏmyŏl Mekŏnijŭm kwa Kŏmjikok ŭl Chungsim ŭro" [Study on an aspect of music regulation under the Yusin system: centered on mechanisms of ban and banned songs], fournal of Democracy and Human Rights 11, no. 2 (2011): 67-96.

${ }^{13} \mathrm{~A}$ study by sociologist Jin-ah Lee is one of the very few studies that include the discussion of the kŏnchŏn kungmin kayo practice of the 1960s, along with an insight into changes in TV and radio programming that reflected both the ban of some popular songs and the rise of the kŏnchŏn kungmin kayo movement. Jin-ah Lee, "1960nyeondae Kayo fŏnghwa Undong kwa Kŏnchŏn Kungmin Kayo Changchul" [Song purification movement and the making of kŏnchŏn kungmin kayo during the 1960s], The Korean Sociological Association 6 (2009): 391-408.
} 
and economic dimensions of the Park era. ${ }^{14}$ I build upon those studies as I examine the rise of kŏnchŏn kungmin kayo in the context of the Park government's efforts to rebuild Korea's economy. Through such investigation, this essay will show that kŏnchŏn kungmin kayo, which today has become an emblem of Park's oppressive state control of the everyday lives of Koreans, are the first-hand records of the sentiments, ideas, and tropes that drove the sweeping modernization of South Korea during what was the country's drastic transition from a war-stricken economy to today's well-to-do society. ${ }^{15}$

\section{The 1960s and the Drive for Betterment}

The early 1960s was one of the most politically tumultuous periods in the modern history of Korea. A massive student uprising, known as the April 19 Revolution, forced South Korea's first president Syngman Rhee (1948-1960) to resign on April 25, 1960. ${ }^{16}$ In the wake of the revolution, Prime Minister Chang Myung became Korea's actual leader, while the elected President Yun Bo-seon, previously Rhee's vice president, remained titular head of the country. However, the new government failed to earn the trust of the ruling Democratic Party, placate the public, or motivate the demoralized police to operate. After a period of persistent internal turmoil and disorder, on May 16, 1961, Military General Park Chung-Hee led a coup d'état with his Military Revolutionary Committee. While the military coup put an end to the unruliness, it also marked the beginning of the Park era, the eighteen-year-long regime marked by both remarkable economic advancement and despotic authoritarianism.

From the moment he rose to power, Park single-mindedly emphasized the notions of "nation" (kukka) and "national" (minchok). The idea of the nation as a collective entity that faced common goals and a shared destiny is plainly laid out in the Revolutionary Pledge of the Supreme Council for National Reconstruction, announced nationwide immediately following the military coup in 1961. The pledge proposed six primary tasks: (1) engaging in anti-communist acts; (2) abiding by international treaties and the United Nations Charter, and reinforcing ties with the free world, including the US; (3) reconstructing the nation by purging corruption; (4) rebuilding the country's economy to achieve self-reliance; (5) strengthening the military to prepare for reunification of the nation; and (6) returning power to the civilian population once the previous five tasks had been fulfilled. ${ }^{17}$ The last proposal was only partially realized, leading to Park's assassination in $1979 .{ }^{18}$ The pledge defined collective aspirations for the Korean

\footnotetext{
${ }^{14}$ See, among others, Meredith Woo-Cumings, Race to the Swift (New York: Columbia University Press, 1991); Moon Seungsook, "The Cultural Politics of Remembering Park Chung Hee," The Asia-Pacific Fournal 19, no. 5 (2009), https://apjif.org/-Seungsook-Moon/3140/article.html; Byung-Kook Kim and Ezra F. Vogel, eds., The Park Chung-Hee Era (2011).

${ }^{15}$ From here on, "South Korea" will be referred to as "Korea," except in places where both Koreas are discussed within the same paragraph.

${ }^{16}$ Despite public contempt for his inadequate leadership of twelve years, Rhee was reelected as the president of Korea in March 1960 as a result of ballot manipulation. When a group of high school students in a southern city of Masan demonstrated against the outcome of the election, the military fired on the students, killing many of them, and the incident led to a series of massive riots throughout the country. On April 19, college students in Seoul marched to the president's office in demonstration, and just a couple of days later, the spurned president resigned and was exiled to Hawaii. See Bruce Cumings, Korea's Place: A Modern History (New York: W. W. Norton, 2005), 342-352.

${ }^{17}$ Ibid., 96. These pledges appeared in newspapers and were announced on the radio. Kyunghyang Shinmun, May 21, $1961,4$. Translation mine. All translations of Korean language original sources are mine unless otherwise acknowledged.

${ }^{18}$ Park won the presidential election when the military government came to an end and the national assembly reopened in 1963. After being re-elected in 1967 and staying in the office for four subsequent years, in 1972, he declared Yusin, a presidential order that dismissed the national assembly, changed direct presidential election to indirect election, and brought all three branches of the government under the control of the president. He was assassinated on October 26, 1979 by his own security chief Kim Jae-kyu. See Don Oberdorfer and Robert Carlin, The Two Koreas: A Contemporary History (New York: Basic Books, 2014), 22-38 and 87-105.
} 
people and, by identifying communists as the country's common enemy and underscoring its interaction with foreign countries, brought attention to Korea's position in an international context. As will be shown below, such dispositions helped heighten the sense of national identity among Korean people at that time.

Throughout his presidency, Park kept Korea's economic development as the central goal of his government with subtle variations in rhetoric over time: the first five years (1961-1966) were focused on rebuilding the country, the second phase (1967-1971) on modernization, and the last stage (1972-1979) on cultivating a strong collective identity. ${ }^{19}$ With these plans, Park sought to develop a distinctive national identity that could create a sense of oneness, and fundamentally, to use that collective power to accelerate Korea's modernization process and economic development. He made this objective clear not only to the Korean people but in the international arena as well. For instance, during a meeting with the US Secretary of State David Dean Rusk in November 1961, Park delivered a speech that outlined his intention to render Korea's economic improvement the core objective of his government. Notably, as he asked for the help of the US, he emphasized economic betterment as the necessary condition to maintain democracy in Korea:

The purpose of our revolution was to instill the spirit of unity so that democracy could strengthen in Korea, which would then allow our country to become the stronghold to respond to your country's goals. The root of democracy that we have planted requires nutrition, which is economic development. We are fully aware that democracy cannot be sustained without a proper standard of living for all people of Korea and an increased national productivity. We have established a five-year-long economic development plan that focuses on the key industries that are important players in strengthening the root of democracy. ${ }^{20}$

As evident in this speech, Park regarded economic development and solid instilment of democracy in Korean society as intertwined. Not only that, he saw economic wellness as a prerequisite for achieving a healthy democracy. Such a governing philosophy led him to place rapid economic development as the core value above all else, including human rights and equal opportunities. ${ }^{21}$

The reason Park laid heavy importance on material well-being was straightforward: Korea's economy was in a dire state. Since its liberation from Japanese colonial rule in 1945, the country's chances of economic development or modernization were quelled by the outbreak of the Korean War, which devastated its infrastructure and deepened the ideological divide among its people. Having gained political power as a result of a military coup in the midst of deep societal chaos, Park was in a position to prove himself to the Korean people with drastic and palpable improvements in living standards. ${ }^{22} \mathrm{He}$ justified his coup by criticizing the previous government's economic state as a "subordinate economy" (yesok kyungje) or an "aid economy" (wonjo kyungje); he then associated economic development with notions of selfreliance and national pride. He believed that, in order for Korea to break free from extreme poverty, it was crucial for its people to dispose of the self-destructive beliefs that had been ingrained in their minds

\footnotetext{
${ }^{19}$ Yi Pyŏng-ch‘ŏn, ed., Kaebal Tokchae wa Pak Chŏng-hŭi Sidae: Uri Sidae ŭi Chŏngch i Kyŏngjejŏk Kiwŏn [Development dictatorship and the Park Chung-Hee era: the political and economic origins of our time] (Kyŏnggi-do P'aju-si: Ch'angbi, 2003), 40 .

${ }^{20}$ Dong-a Ilbo, November 17, 1961, 1.

${ }^{21}$ This extreme push for economic development at the expense of human rights deepened the US distrust of Park. See Lyong Choi, "Human Rights, Popular Protest, and Jimmy Carter's Plan to Withdraw US Troops from South Korea," Diplomatic History 41, no. 5 (2017): 933-958, https://doi.org/10.1093/dh/dhx030.

${ }^{22}$ Dobin Yim, "Pak Chŏng-hŭi Chŏngbu Kukchŏng Unyŏng ŭi Mokpyo mit Panghyang” [Park Chung-Hee government's governance objectives and directions] in Taehan Min'guk Yŏktae Chŏngbu Chuyo Chŏngch'aek kwa Kukchŏng Unyŏng: 2. Pak Chŏng-hŭi Chŏngbu [Chronology of key policies and governance of the governments of the Republic of Korea: vol. 2. Park Chung-Hee government], ed. Han'guk Haengjŏng Yŏn'guwŏn [Korea Institute of Public Administration] (Seoul: Tosŏ Ch'ulp'an Taeyŏng Munhwasa, 2014), 37.
} 
through their colonial history, and replace those old dispositions with the new ethos of confidence and striving for betterment. These objectives were announced explicitly during his first New Year's address as the president of Korea in 1964, during which he delineated three challenges that Korea must face in order to move forward. They were: (1) reunification of the Koreas by resolving to make democracy triumph and fighting against communist aggressions; (2) defeating poverty; and (3) possessing, collectively, an independent and proactive mindset instead of being bound by passivity, dependency, and partisanship that had plagued the minds of Koreans for a long time. ${ }^{23}$

The last of these challenges was repeatedly emphasized and propagated throughout the Park regime. Notably, the government initiated the Kukka chegon kungmin undong, or "national reconstruction campaign," in 1961. One of the most powerful domestic propaganda tools of the Park regime, the initiative was focused on promoting "national morality" (kungmin toŭı). Here, "morality" not only indicated obvious qualities such as diligence, frugality, and prudence, but also included cultural measures to improve social conditions and refine the public sentiment. The regime devised and advocated meticulous social mores. For instance, citizens were encouraged to refuse luxury import goods and to use plain clothing instead. Gambling and indigenous shamanic rituals were forbidden since both were designated as harmful to public morals. Literacy campaigns were enacted to abolish illiteracy. Government-subsidized athletic events took place at schools, municipal offices, and civilian organizations to boost public morale. The government even formulated a set of physical exercises, called chaegŏn ch'ejo [reconstruction exercises], of which verbal instructions were set to choral music. ${ }^{24}$ Citizens were obliged to gather at schools or civic centers each morning and follow along the recorded instructions played on the radio. ${ }^{25}$ Furthermore, in order to promote a "healthy" cultural palette, popular songs exhibiting strong foreign influences, especially those in Japanese style (waesaek), were banned, driving many beloved songs out of the public sphere. ${ }^{26}$

With such sweeping "restructuring" of social mores, Korean people were to be placed on a fast track to seeing an affluent country. The irony was that those measures, which only grew more severe throughout the Park regime, made Korea closer to an autocratic country than the democratic one that Park advocated in his speech at the office of the US Secretary of State in 1961. In other words, Park ChungHee, who considered breaking the chains of poverty the basic condition for democracy, focused on economic improvement at the expense of individual freedom or the common values of democracy. He maintained the same strategy during his nearly twenty years of presidency, only tightening civilian regulations in reaction to increasing hostility toward his autocratic rule both among the public and within his cabinet.

\footnotetext{
23 “1964 nyŏn taet'ongnyong yŏndugyoso" [The State of the National Message, 1964], Presidential Archives, http://pa.go.kr/research/contents/speech/index.jsp.

${ }^{24}$ The music was composed by Pak Mokwŏl, who composed a number of songs for the Park Chung-Hee regime throughout the 1960s. Recording of chaegonn ch'ejo, along with the instructions for the exercise, can be heard at: https://www.youtube.com/watch?v=NE985GMMTnE.

25 “Chegŏn kungmin ch'ejo hesŏl” [Explanation on reconstruction national physical exercise], Kyunghyang Shinmun, July 12, $1961,4$.

${ }^{26}$ One of the most prominent examples is "Tongpaek Akassi" [Camellia lady] by Lee Mi-Ja, which had topped the Korean popular music chart for more than 30 weeks in 1964 but disappeared suddenly from the public after being banned for resembling Japanese style and expressing excessive sentimentality. This song can be heard at: https://www.youtube.com/watch?v=gOSkGqpIBgU. Also see Seung-Ah Lee, "Decolonizing Korean Popular Music: The 'Japanese Color' Dispute over Trot," Popular Music and Society 40, no. 1 (2017): 102-110, https://doi.org/10.1080/03007766.2016.1230694.
} 


\section{Songs to Uplift the Nation}

Throughout the course of implementing these new regulations, Park Chung-Hee used songs as an important propaganda tool to promote national awareness and uplift the spirit of the public. As mentioned earlier, the Supreme Council for National Reconstruction banned popular songs that were considered too sentimental or carried excessive foreign influences during the 1960s. The banned popular songs were then replaced with "healthy national popular songs" (kŏnchŏn kungmin kayo), songs whose lyrics carried acceptable messages by the government's standard. In order to win the support of the general public, the government sought ways to make average citizens participate in creating the new soundscape. Thus, in September 1961, the Bureau of Public Information announced a special "call for a national song." In this announcement, kungmin kayo was defined as "national songs" that were "suitable for the public sentiment," would "help redress corrupted national morality and national spirit, conforming to the ideals of the revolution," and make "the public life merry and just."27 Several songs were selected from this competition, the most widely sung among them being "Saesallim ŭ norae" [The song of new livelihood], "Sae nara neun purŭnda" [A new nation is calling], and "Sae ach'im" [New morning].28 These new songs praised or encouraged the spirit of national rebuilding. For example, the message of "Sae ach'im" (Example 1 below) is rife with sanguine optimism: ${ }^{29}$

Verse 1: The Sun is bright on this cheerful morning; you head to the field and I to the factory / Now our lives prosper; leaving our destitute past behind / You and I, through national reconstruction, let us live well.

Refrain: Let us live well; reconstruction, reconstruction, let's salute each other / Let us live well / the mission of May 16 with earnest smiles.

Verse 2: The sky is high on this bright morning; you are at the front line, me at home / Now the anti-communist country sees the light; leaving our troublesome days behind / You and I, through anti-communist reconstruction, let us live well.

Verse 3: The morning of sonorous military music of the revolution; with revolution of our industry, society, and homes / Now our country becomes rich and powerful, leaving our intemperate past behind / You and I, through reconstruction of our lives, let us live well.

The motto of the refrain, "let us live well" (ch'al sarapose), is a crude expression of the desire to rise to affluence, which was one of the most frequently used slogans of the Park government. In the second verse, the "I" is probably a woman, who sings of typical gender responsibilities of the time: men being "at the front line" of earning a livelihood while women take care of the home. Depicting an ideal household and good-spirited, hard-working citizens, the lyrics fulfill the "requirements" for a healthy national song. Moreover, by linking May 16 - the day of Park Chung-Hee's military coup d'état-to reconstruction and revolutionary spirit, the song draws a positive image of the new regime. In "Sae nara nŭn burŭnda"

\footnotetext{
${ }^{27}$ Kyunghyang Shinmun, September 5, 1961, 3.

${ }^{28}$ Dong-a Ilbo, January 18, 1962, 3. The composers of selected songs were awarded by the Office of Public Information of the Supreme Council for National Reconstruction, which called these new songs, "food for the soul of the citizens." "Kungmin Kayo Dangsŏnja Pyochang [Awarding winners of kungmin kayo]," National Archives of Korea, accessed October 10, 2018, http://theme.archives.go.kr/viewer/common/archWebViewer.do?singleData =Y\&archiveEventId =0049286992.

${ }^{29}$ Translations of all the lyrics in the article are mine.
} 
(Example 2 below) by high school teachers Dongil Oh and Wuyŏng Ham, the lyrics plainly praise the land and the long history of Korea, and the refrain urges the listener to "go forward" to answer "the new nation's calling."

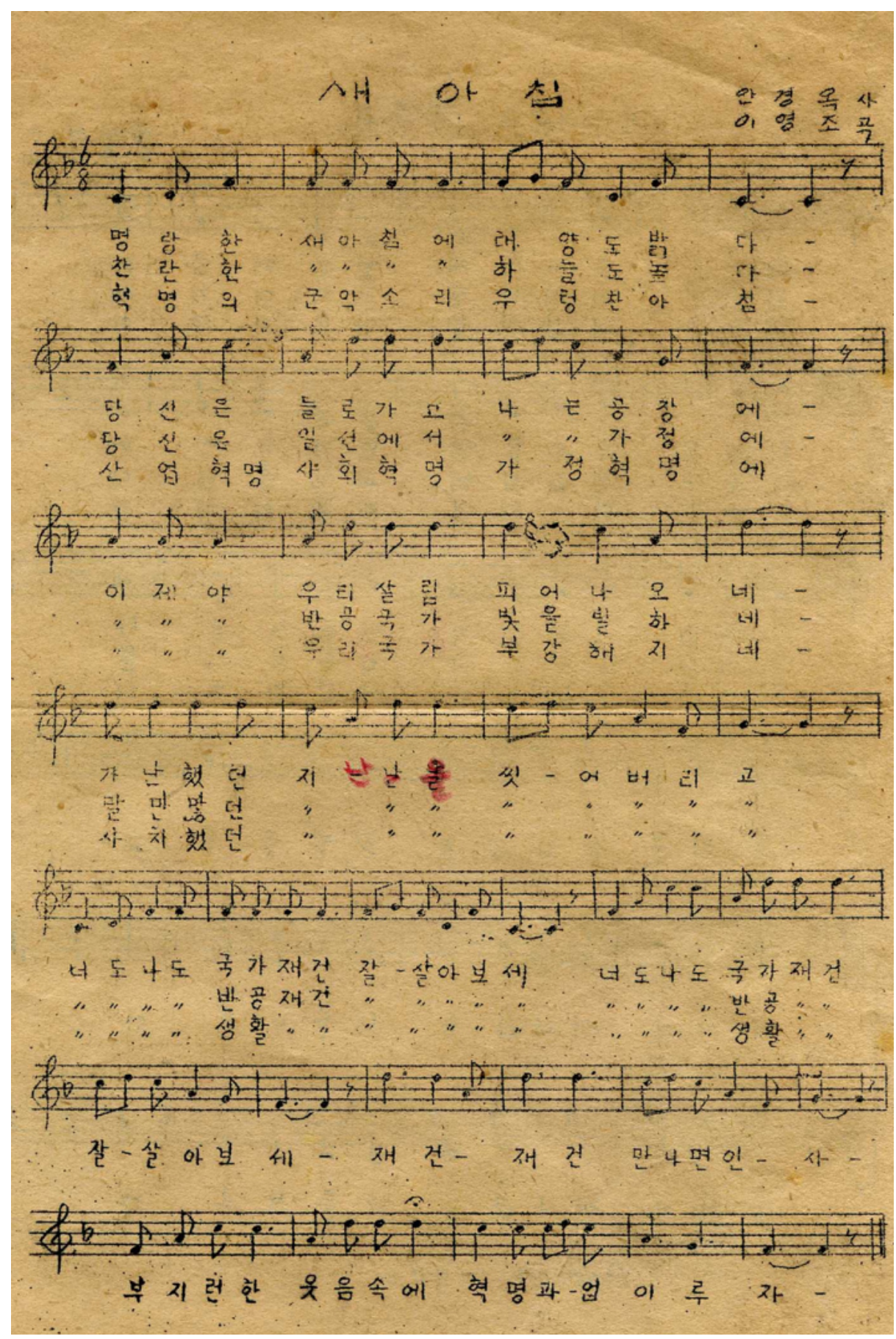

Example 1: The score for "Sae a'chim" [New morning] $]^{30}$

Video recording:

http://www.ehistory.go.kr/page/view/movie.jsp?srcgbn=KV\&mediaid=10501\&mediadtl=22532\&gbn=MH

\footnotetext{
${ }^{30}$ This score was published in a periodical targeted for farmers: Kyŏng-ok Ah and Yŏng-cho Lee, "Sae a'chim," Nongch'on mun'go: Onul ŭ Hŭngbu wa Nolbu (Seoul: Senarasa, 1962), 30. This score is now out of print, but a stenographic copy of the original is available on the following website: $\mathrm{http} / /$ book4949.co.kr/shop/shopdetail.html?branduid=136496 (last accessed October 14, 2019).
} 


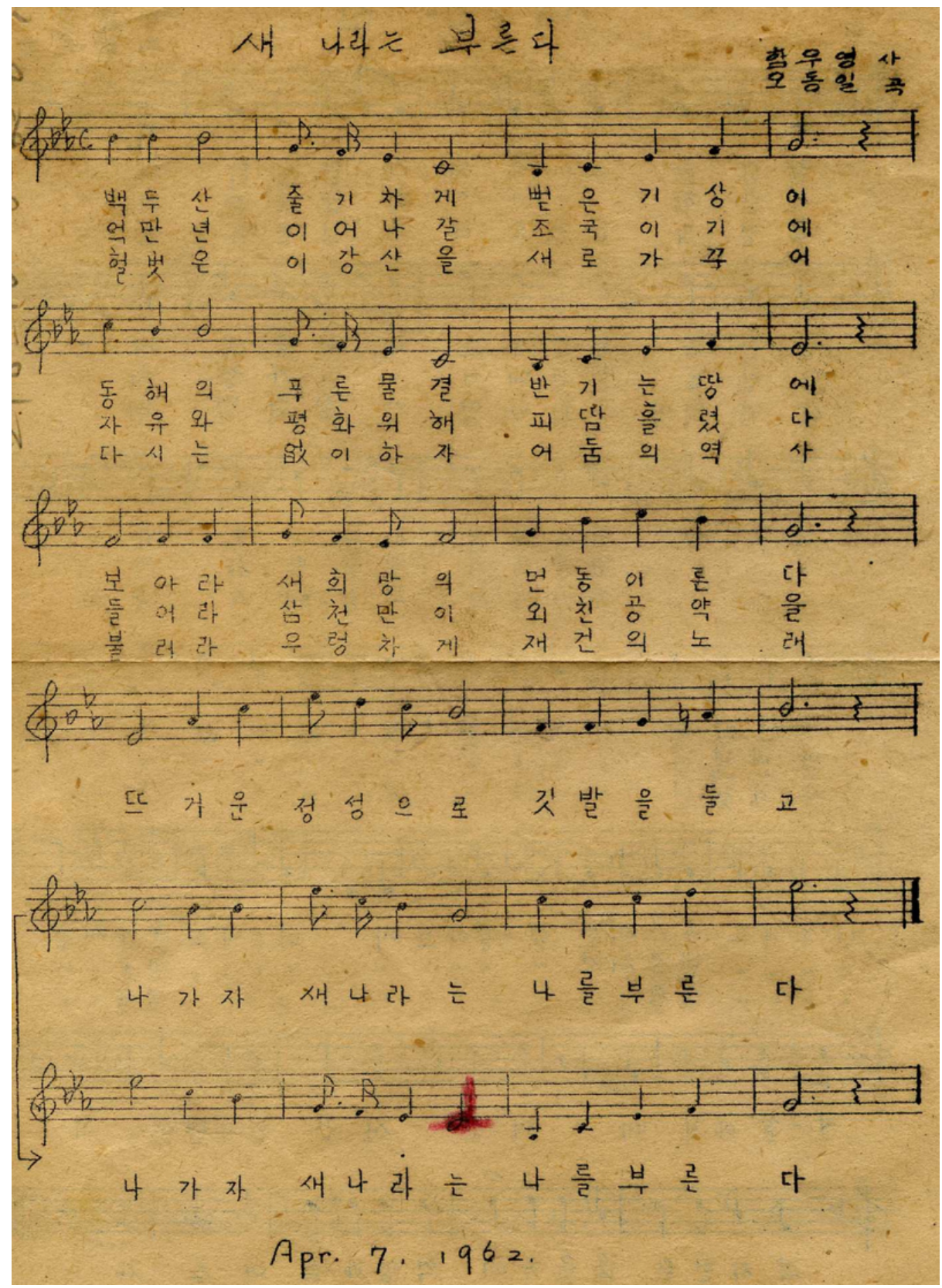

Example 2: The score for "Sae nara nun burunda" [A new nation is calling] ${ }^{31}$ Video recording:

http://www.ehistory.go.kr/page/view/movie.jsp?srcgbn=KV\&mediaid=10501\&mediadtl=22517\&gbn=MH

It should be noted that both songs are written using Western musical conventions, a common practice for Korean musicians since the early twentieth century. "Sae nara nŭn burŭnda" is written in the

\footnotetext{
${ }^{31}$ Wuyŏng Ham and Dongil Oh, "Sae nara nŭn buründa." This stenographic copy of the original was obtained on November 19, 2015, from the following website: http://book4949.co.kr/shop/shopdetail.html?branduid=39031 (last accessed October 14, 2019).

${ }^{32}$ It may seem paradoxical that songs that are meant to assert an independent national identity were set to Western style music. While the notation system of Korean traditional music, known as chŏngganbo, has always remained a specialized knowledge, the Western notation system was far more widely known and used by Korean musicians since its introduction to Korea through Christian missions at the end of the nineteenth century. See Hyun Kyong Hannah Chang, "Exilic Suffering: Music, Nation, and Protestantism in Cold War South Korea," Music and Politics 8, no. 1 (2014), http://dx.doi.org/10.3998/mp.9460447.0008.105.
} 
bright and triumphant key of E-flat major, although we cannot be sure if the composer was aware of the connotation of heroism associated with that key as understood in Western art music. ${ }^{33}$ In a marching 4/4 meter, the song is comprised of a simple melody suitable for public singing. The arrival at E-flat at the end of an ascending melody also effectively conveys the spirit of resolution. Yet, despite features of Western music, the overall sound evokes folk music, which was still loved and frequently sung by the Korean people at the time. The folk-like sound results chiefly from the fact that the melody is built from a pentatonic scale, except for the brief moment of "tonicization" of B-flat (using the fourth and the raised fourth scale degrees) in the fourth line. It is also notable that there is no accompaniment, probably because the songs were meant to be sung by the masses at any time or in any space.

\section{Two Key Values: Chegon (Reconstruction) and Chuch'esŏng (Self-reliance)}

In both songs, the emphasis on national reconstruction is prominent, as in the third line of the third stanza in "Sae nara nün buründa," which reads, "Sing, loudly, the song of rebuilding." Reflecting the core values of the kukka chegon kungmin undong (national reconstruction/rebuilding campaign), the preoccupation with nation rebuilding during that period can be sensed with the numerous songs that unabashedly emphasize that idea. One such song was titled “Noraeshirŭn Chegŏnyŏlcha” [Reconstruction train carries songs], released in 1963. Chegonho was the name of the train that ran between South Korea's northernmost city, Seoul, and the southernmost city, Pusan, from 1962 to 1969. Running at over $100 \mathrm{kmh}$ (about $62 \mathrm{mph}$ ), Chegonho was then the country's fastest train, thus the symbol of Korea's rapid modernization and urbanization. The lyrics show that the song was closer to a propaganda song than a popular song by today's standard:

Noraeshirŭn Chegŏnyŏlcha [Reconstruction train carries songs]

Choochoo the train runs

Over the mountain, cross the water, over the hill,

Runs Runs Chegonyŏlcha [train of reconstruction], carrying songs

To mountain villages, to remote villages, to the town of the pretty girl.

Laughter blossoms, rebuilding sprouts.

Let's sing

Choochoo the train runs

Rain or snow, without rest

Runs Runs Chegonyŏlcha [train of

reconstruction], carrying songs

Cities and countrysides connect through

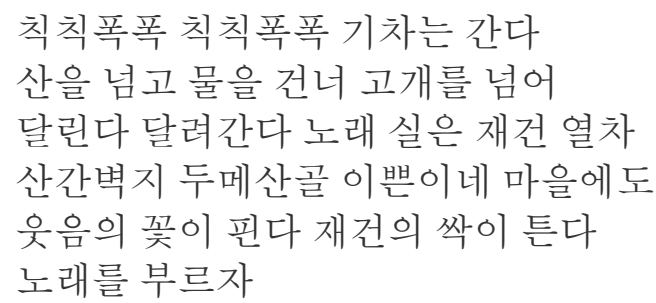

노래를 부르자

\footnotetext{
${ }^{33}$ The association between the key of E-flat major and heroism has a long history in Western music. The most famous examples of this relationship come from Beethoven's "heroic-period," including the Third Symphony, also known as "Eroica," and the Emperor Concerto are in E-flat major. Wagner and his contemporaries also regarded E-flat major as a symbol of heroism. See Michael P. Steinberg, The Trouble with Wagner (Chicago: The University of Chicago Press, 2019 ), 37. Furthermore, well before Beethoven's time, the Italian music theorist Francesco Galeazzi called E-flat major "a heroic key, extremely majestic, grave and serious." Francesco Galeazzi, Elementi teorico-practici di musica (1796), as translated into English in Rita Steblin, A History of Key Characteristics in the Eighteenth and Early Nineteenth Centuries (Rochester, NY: University of Rochester Press, 1996), 111.
} 
sisterhood. In the town of Samdol [ordinary Joe] Love blossoms, happiness sprouts Let's sing
사랑의 꽃이 핀다 행복의 싹이 튼다

노래를 부르자

Throughout the 1960s, the idea of chegon [reconstruction/rebuilding] was excessively and almost bluntly celebrated: it seems that anything could have been paired up with chegon to become kŏnchŏn kungmin kayo. The titles of such songs ranged from unexceptional ones like "Chegonho nŭn dalrinda" [Train of rebuilding runs], "Chegŏn ü̆ norae" [Song of rebuilding], and "Chegŏn ch'ejo ŭi norae" [Song of rebuilding exercise] to a more curious one such as "Chegon pupu" [Rebuilding couple]. The publication in 1962 of Chegŏn kayojip, a collection of 20 kŏnchŏn kayo songs composed by the famous children's song writer Yun Keukyŏng, also seems peculiar, because the composer had retired after Korea's liberation and had been living in isolation since then. ${ }^{34}$ As with the previously discussed songs, all of these songs were also written in Western style. For instance, "Chegŏn üi norae" [Song of rebuilding] begins with a stately fanfare and soon turns into a resolute march in a minor key. Performed by a mixed choir, the song invokes an air of solemn determination as well as a sense of hope, especially with its ending in a bright major key and the declamatory, ascending final melody.

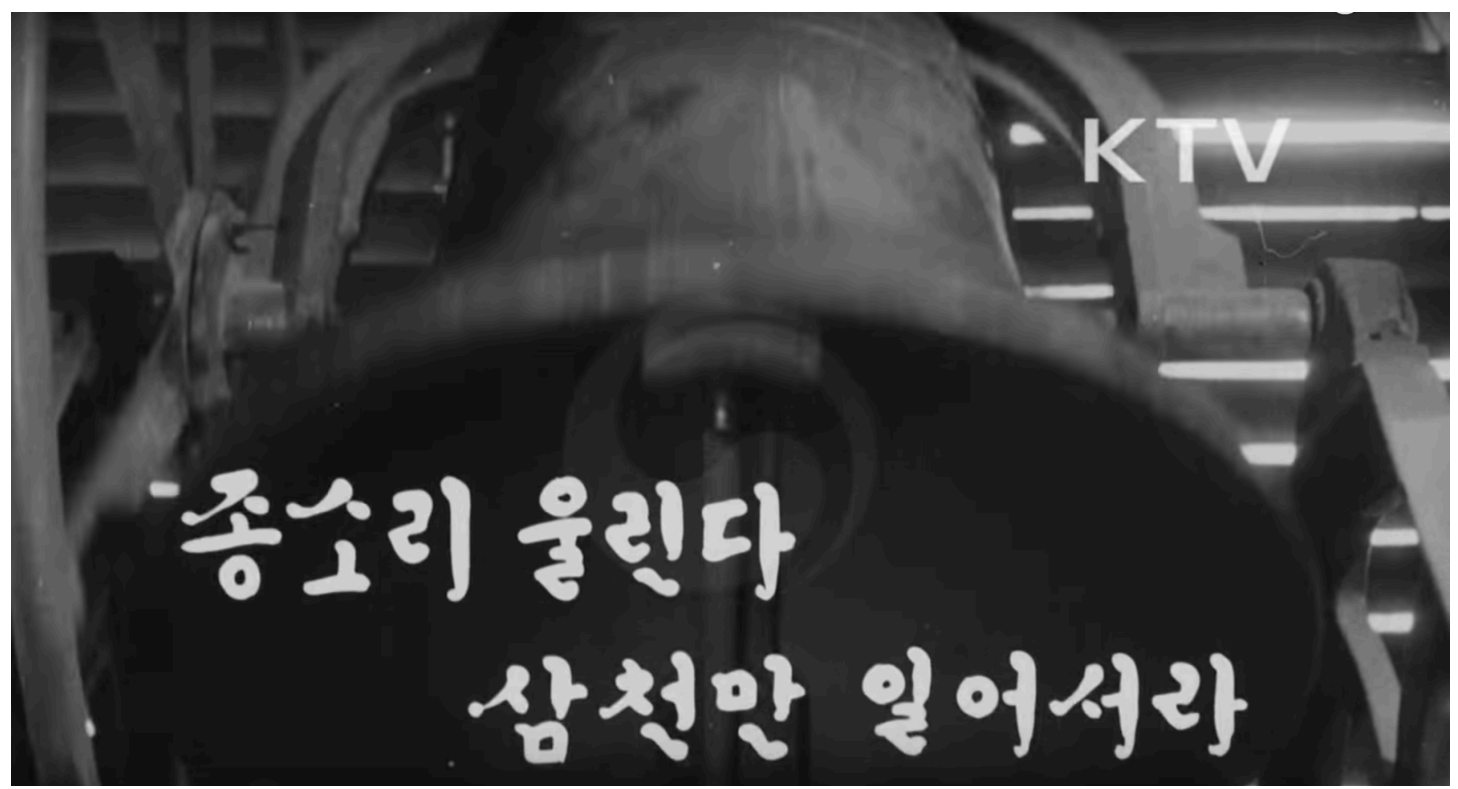

Recording: "Chegŏn ŭ norae" [Song of rebuilding] $]^{35}$

Watch video: http://dx.doi.org/10.3998/mp.9460447.0014.105.

With the official emphasis on collective national rebuilding, Korean people's perceptions of selfhood and awareness of national identity vis-à-vis other countries underwent a significant change in the 1960s. Although defining the nature of a transformation of a national identity is not an easy task, reading journals and newspapers from the 1960s reveals that the notion of chuch'esóng-translated as self-reliance, selfhood, identity, subjectivity, or independence-prevailed in the South Korean public and intellectual

\footnotetext{
${ }^{34}$ Kyunghyang Shinmun, February 6, 1962, 3. It needs to be mentioned that, other than the announcement of the publication of this collection in the cited newspaper article, I have not been able to locate this collection of songs from 1962 or any indication of it being used in the public sphere. However, it is true that a couple of Yun's songs were included in the list of suggested kŏnchŏn kayo by the Bureau of Public Information throughout the 1960s.

${ }^{35}$ Original video link: https://www.youtube.com/watch?v=G-111MCl4i8.
} 
discourse by $1965 .{ }^{36}$ The word chuch'esŏng began to appear in public discourse in 1945 , the year that Korea was liberated from Japanese rule. In 1965, however, the use of the word saw an unprecedented surge. The Korean philosopher Kyu-ho Yi (1926-2002) observed in a brief explication of the word chuch'esŏng, "it is the most frequently used word in our society today." ${ }^{37}$ When the term was mentioned in public contexts, it was often done so in a derogatory tone of self-reproach, resenting the lack of national chuch'esŏng and advocating cultural "purity," as revealed in a newspaper article from 1965:

Sitting in front of the radio or the TV, the dregs of filthy decadence penetrate into our homes. These strands of decadence are an imitation of the lethargic backstreets of foreign countries. Instead of sonorous choruses to lift our spirit and to encourage the advancing and building of tomorrow, songs unqualified as songs, shows unqualified as shows, decadent melodies of foreign popular songs, to which we shake our bodies yet which we cannot even pronounce well, corrupt our vision. This life of a puppet, dancing to the melodies of others while losing ourselves, this is one sad portrayal of Korea, tainted by colonial practices. ${ }^{38}$

Notwithstanding the harshness of the tone that vaguely resembles the chauvinistic language of today's North Korea, the examples of "taints by colonial practices" given in the article indicate that the 1960s may indeed have been a time of worrisome cultural confusion in Korea. A high school student who claimed to have forgotten the Korean language after a two-month visit to the United States, and period films that portray Korean people from historical times as Japanese Samurais or American cowboys, were read as clear signs of deprivation of cultural chuch'esong. As the title of the article suggests, in the 1960s, a "colonial mentality" and "astounding loss of the self" were some of the most alarming vices that ought to be vanquished by a robust and healthy national identity.

The importance of the notions of national identity and self-reliance is confirmed in the remark made by the renowned Korean historian Hyungjin Yu in 1969: "Nearly all aspects of the daily lives of ordinary people of the 1960s were focused around the ideas of identity or autonomy." 39 Yu believed that this phenomenon was epitomized in the Charter of National Education, declared on December 5, 1968, which included the key phrases "historical mission of reconstructing the nation" and "creation of the new history." According to Yu's article, the obsession with forming a new national identity in the 1960s was the result of self-reflection on the blind reception of Western culture-often understood as "materialistic" culture-of the previous decades. Because of the US military presence in Korea immediately after the liberation in 1945, American popular culture penetrated into Korea rapidly throughout the late 1940s and 1950s. In addition, vestiges of the Japanese colonial era continued to surface in Korea's cultural scene. Yu saw the 1960s as the time of an awakening, a collective arrival at the awareness that Korea's culture had become a mashed hodgepodge of foreign elements. That awareness was emerging as a powerful reflection on national selfhood.

Two major events led to the rise of the notion of chuch'esŏng in the 1960s: the normalization of Japan-Korea relations and Korea's participation in the Vietnam War. Korea's normalizing relations with Japan had been a US interest in East Asia since the 1940s, yet neither president before Park was willing to

\footnotetext{
${ }^{36}$ Before further discussion, it is worthwhile to distinguish the notion of chuch'esŏng from a similar-sounding word, chuch'esasang. While both words contain the root word chuch'e ("subject" or "self"), the two carry a different political significance. The latter, chuch'esasang, is North Korea's fundamental governing ideology of self-reliance, which began to form in the late 1950s and became ensconced as the Kim Il Sung regime's central creed in 1965. See Victor Cha, The Impossible State: North Korea, Past and Future (New York: Ecco, 2012).

${ }^{37}$ Kyu-ho Yi, "Chuch'esŏng," Kitokkyo Sasang [Christian Ideology] 9, no. 8 (1965): 95.

${ }^{38}$ Kyunghyang Shinmun, January 19, 1965, 1.

${ }^{39}$ Kyunghyang Shinmun, December 20, 1969, 5.
} 
come to terms with Japan unless it gave enough reparation money and apologized for its colonial wrongdoings. ${ }^{40}$ Because Park prioritized economic benefits before public sentiment, he pushed the normalization effort by tempering the conditions placed on Japan. Also, ongoing threats from North Korea made it all the more necessary for South Korea to rely on Japan; strengthening South Korea's anticommunist stance by becoming allies with Japan, itself an ally with the United States, was imperative to achieve economic and political stabilization. ${ }^{41}$ Although many at the time regarded Park as pro-Japanese after the normalization, Park in fact believed that removing traces of Japanese colonialism was one of the important strategies of building Korean nationalism during this time, resulting in banning many songs that were considered to be in the style of Japanese popular songs. ${ }^{42}$

\section{The Vietnam War and kŏnchŏn kungmin kayo}

If normalizing relations with Japan heightened Korean people's awareness of a national identity, involvement in the Vietnam War led Koreans to place themselves in an international context. South Korea sent more than 300,000 soldiers to Vietnam, the second-largest number of troops after the US military. As with the normalization, political and economic benefits were powerful motivations for Park Chung-Hee to send troops to Vietnam. In 1961, North Korea concluded mutual defense and assistance treaties with the Soviet Union and the People's Republic of China, making it imperative for Park to establish himself as a strategic ally of the US. ${ }^{43}$ Winning the trust of the US was especially important for him because the US was disapproving of his military coup; moreover, the conservatives of both the US and South Korea suspected that he was sympathetic to communism. ${ }^{44}$ Supporting the US war was a way for him to redress his relationship with the country's most significant benefactor and to clarify his position as anticommunist and pro-America. ${ }^{45}$ Furthermore, by sending troops to the Vietnam War, Korea received civilian and military subsidies of more than one billion dollars from the US between 1965 and $1970 .^{46}$ The procurement enabled South Korea's heavy industries to take off and became the foundation of its economic growth through the 1980s.

\footnotetext{
${ }^{40}$ Woo-Cumings, Race to the Swift, 85. Rhee was an intrinsically anti-Japanese nationalist, and his primary focus was the USKorea alliance to curb the communists. Jung-Hoon Lee, "Normalization of Relations with Japan: Toward a New Partnership," in The Park Chung Hee Era, 433.

${ }^{41}$ Sang Mi Park, “The Paradox of Postcolonial Korean Nationalism: State-Sponsored Cultural Policy in South Korea, 1965Present," The Fournal of Korean Studies 15, no. 1 (2010): 72.

${ }^{42}$ Lee, "Normalization," in The Park Chung-Hee Era, 434. Ironically, many of Park's policies were adopted from Japanese examples, especially those from the Meiji Restoration (1868-1912). For example, historian Sang Mi Park argues that the New Village movement (saemaŭl undong) of the 1970s, the nationwide campaign for comprehensive economic and social development in Korea, was also similar to the New Life movement (shin seikatsu undo). Park, "The Paradox,” 75-80.

${ }^{43}$ Historian Min Yong Lee argues that Korea's dispatch of troops to Vietnam was motivated by political, rather than economic, reasons, and suggests that South Korea was able to "acquire modern armed forces with combat experience" by participating in the Vietnam War. Lee, “The Vietnam War: South Korea's Search for National Security,” in The Park Chung Hee Era, 404-405.

${ }^{44}$ Ibid., 406-704. Also see Cumings, Korea's Place, 354-356.

${ }^{45}$ Min Yong Lee assesses that Park's efforts to gain US approval and support were successful, as shown in the US support of Park's fiscal policies as well as declaration of martial law in 1964. Lee, “The Vietnam War," 407. Also, studies have revealed that dispatching troops to Vietnam was a tacit agreement between the US and Korea: during the normalization talks, Park offered to provide military support for the United States in Vietnam, and in return, US National Security Advisor McGeorge Bundy pledged to help Korea with its negotiations with Japan through normalization. Lee, "Normalization," 447.

${ }^{46}$ Frank Baldwin, “America's Rented Troops: South Koreans in Vietnam,” Bulletin of Concerned Asian Scholars 7, no. 4 (1975): 37-38, https://doi.org/10.1080/14672715.1975.10406389. Quoted in Charles K. Armstrong, The Koreas (New York: Routledge, 2014), 117, https://doi.org/10.4324/9780203079652. A news article from July 30, 1964, also reported that the payment for Korean troops would be provided by the US at six dollars per day for officers and one dollar per day for privates. Kyunghyang Shinmun, July 30, 1964, 1. According to World Bank, South Korea's GDP per capita that year was 123.59 USD.
} 
In addition to economic and political benefits, participating in the Vietnam War had a psychological significance for the Korean people. The US war in Vietnam was the first foreign war-fighting in a foreign country and in a war of foreign countries-in Korea's recent history. It was also the first war in which Korea took part for an ideological cause with international relevance. Arguably, it was one of the first incidents in modern history that placed Korea on the international scene, neither as a colonial subject nor as a beneficiary, but as a collaborator. One of the earliest recorded public responses to the announcement of the dispatch in 1964 highlighted the significance of Korea's contribution to the peace and security of the free world. ${ }^{47}$ Depicting Vietnam as an anti-communist ally who was undergoing a conflict similar to the one which Korea had suffered just a decade earlier, the author pleaded for national support for the dispatch. ${ }^{48}$ Even though many Koreans grew unfavorable toward the dispatch as the number of Korean soldiers being sent to Vietnam increased in 1965, still others stressed the importance of Korea's contribution, as did this writer:

Vietnam and Korea have had shared responsibilities as anti-communist allies, but now the two countries have even closer connections. We have a deep interest in every aspect of the state of affairs in Vietnam, as their destiny is linked to our destiny. [...] What we ask of our soldiers is to be good people, not only good soldiers, so that they are regarded as respectable and praiseworthy by the people of Vietnam. Because it is the first time a large number of our soldiers are fighting abroad, they must not forget that their reputation affects the reputation of our people as a whole. ${ }^{49}$

As can be read in this editorial, coming to the new role of a contributor in the international scene strengthened a shared sense of a national identity. It can also be sensed that a collective national identity was being prioritized above an individual identity.

As with many other government undertakings, messages supporting Korea's participation in the Vietnam War were conveyed through songs. In 1966, when Korea dispatched an even greater number of army units than before, military songs began to be actively promoted as part of kŏnchŏn kungmin kayo. The titles of songs that were distributed actively by the government in 1966 are translated as "Here come the Tigers" (nickname of the Capital Mechanized Infantry Division), "Run, white horse" (nickname of the 9th Infantry Division), "We are blue dragons" (nickname of the 2nd Marine Division), "Song of dispatching troops to Vietnam," and "Red scarf" (symbol of the Korean Air Force). ${ }^{50}$ The phenomenon of including military songs in the list of the government-promoted kŏnchŏn kungmin kayo carried into the following year. The translated titles of the selected songs in 1967 were "The march song," "Brave soldiers crossed the ocean," and "The return of a brave soldier." ${ }^{51}$ Because many Koreans were already against sending troops to Vietnam, the decision to send more troops throughout 1966 and 1967 necessitated molding public sentiment in favor of the dispatch. ${ }^{52}$ The Park government utilized kŏnchŏn kungmin kayo to attempt to do just that, as with many other ideas and values that the government wished to promote.

\footnotetext{
${ }^{47}$ Dong-a Ilbo, July 14, 1964, 3.

${ }^{48}$ Ibid.

${ }^{49}$ Kyunghyang Shinmun, January 28, 1965, 2.

${ }^{50}$ The titles of the songs in Korean are "Maenghodŭl ŭ ganda," "Tallyŏra Paengma," "Uri nun̆ Ch'ŏngnyongida," "Wolnam p'abyŏng uı norae," "Bbalgan mahura."

${ }^{51}$ The titles in Korean are "Chŏnchin uй norae," "Yongsadul ŭ badarul gŏnŏtda," and "Doraon yongsa."

52 The number of South Korean soldiers sent to South Vietnam was 20,541 in 1965; 45,605 in 1966; 48,839 in 1967; 49,869 in 1968; 49,755 in 1969; 48,512 in 1970; 45,663 in 1971; and 37,438 in 1972. "Betŭnam chŏnjeng iran?: Che sach'a pabyŏng (9 sadan) ŭn ŏddŏke iruŏchyŏtna?" [What was the Vietnam War: How did the $4^{\text {th }}$ dispatch (the $9^{\text {th }}$ Infantry Division) happen?], PDF file, Institute for Military History 57, accessed October 14, 2019, http://medcmd.mil.kr/user/imhc/download/vetnam/V14.pdf.
} 


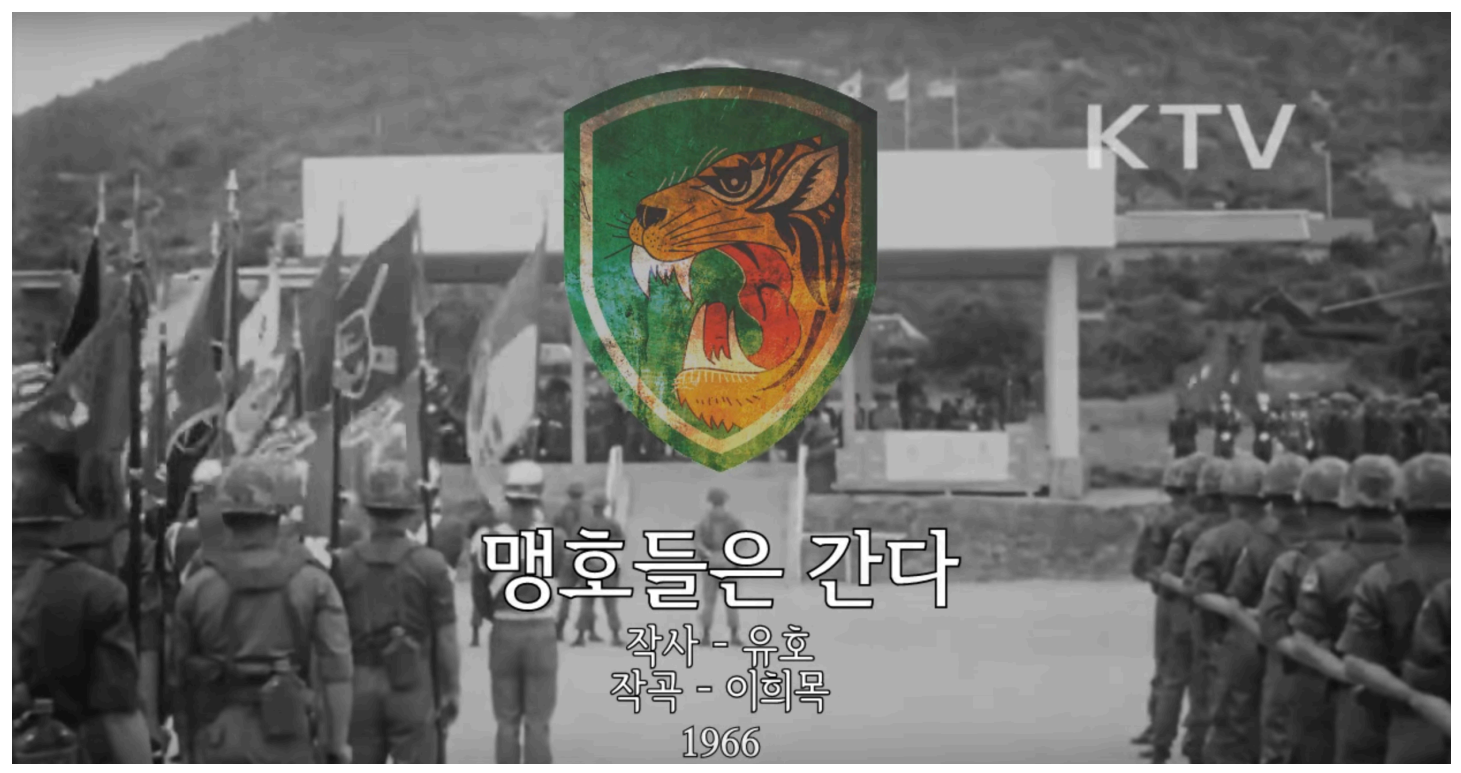

Recording: "Here come the Tigers" 53

Watch video: http://dx.doi.org/10.3998/mp.9460447.0014.105.

\section{Echoes of Songs in New Villages}

As shown thus far, kŏnchŏn kungmin kayo songs were carefully screened and selected, and once chosen, they were distributed strategically. Records of public contests of kŏnchŏn kungmin kayo come from as early as fall of 1961 — the event was plainly titled, "Kungmin kayo pogŭm kyŏngyŏn taehoe" [Contest of people's popular songs for wide distribution]. ${ }^{54}$ Then, in September 1962, the Bureau of Public Information and the Supreme Council for National Reconstruction launched an "echoes of songs" campaign (norae üi meari undong). ${ }^{55}$ The goal of the 52-day-long campaign was to make every citizen learn to sing at least ten kŏnchŏn kungmin kayo songs by encouraging collective singing in various public spaces, such as schools, theaters, and workplaces. The campaign was meticulously outlined and organized, including measures such as mandating all broadcasting companies and music associations to create one kŏnchŏn kungmin kayo per month; engaging all media outlets to distribute the songs; requiring every school, organization, company, and village/town to form a choir and perform once a month; appointing teachers who toured to teach kŏnchŏn kungmin kayo; and holding public kŏnchŏn kungmin kayo singing competitions. Furthermore, the Bureau of Public Information announced a list of suggested songs for public singing, which included the previously examined "Sae a'chim" [New morning] as well as new kŏnchŏn kungmin kayo bearing titles such as "Ilt’ŏro kaja" [Let's go to the workplace] and "Nongminüi pŏshi toě" [As friends of farmers], in addition to a number of well-known children's songs and folk songs. ${ }^{56}$ Notably, some of these songs were composed by composers of Western music, who were

\footnotetext{
${ }^{53}$ Original video link: https://www.youtube.com/watch?v=C hqnFeiunA.

${ }^{54}$ Kyunghyang Shinmun, October 18, 1961, 2.

55 "Norae uı meari undong Kyehwek" [Plans for the Echoes of Songs campaign], National Archives of Korea, accessed October 14, 2019, http://theme.archives.go.kr/viewer/common/archWebViewer.do?singleData=Y\&archiveEventId=0049284368. For an analysis of the campaign, see Un-gyŏng Kim, "Pak Chong-hŭi ch'eje ŭi ŭmak chongch'aek e kwanhan bipanjok yonku” [Critical study of music policies of the Park Chung-Hee regime], Fournal of Korean Political and Diplomatic History 35, no. 1 (2013): 41-70, https://doi.org/10.18206/kapdh.35.1.201308.41. Public announcements of the campaign were made in various newspapers, including Kyunghyang Shinmun, September 3, 1962, 3.

56 "Norae uй meari undong Kyehwek" [Plans for the Echoes of Songs campaign], National Archives of Korea.
} 
professors of music at top universities in Korea. ${ }^{57}$

As the campaign unfolded, amateur choruses sprang up and music competitions at various levels transpired across the country. Government officials were given the duty to teach kŏnchŏn kungmin kayo, sometimes along with simple physical exercises to other workers in their own sub-organizations, so that the songs could be dispersed into the public. ${ }^{58}$ By 1963, "Norae üi meari undong" [Echoes of a song] became the title of a listener-participation radio program; it then became the model for similar radio programs such as "Da hamgge noraerü’ [Let's all sing together] and "Samch'ŏnman üi hapch'ang" [Chorus of thrity million] that launched in the early 1970s. ${ }^{59}$ The nationwide song campaigns took place several times throughout the 1960s and even in the 1970s. For each campaign, the Bureau of Public Information designated at least 10 songs and sometimes as many as 20, including kŏnchŏn kungmin kayo, children's songs, easy art songs, and military songs, which were then announced in newspapers and radios. ${ }^{60}$ Furthermore, in order to increase public interest and participation, countrywide calls for songsof which outcomes were discussed above-as well as a call for lyrics were announced throughout the 1960s. The guidelines for the call for "healthy" lyrics, publicized by the Donga Broadcasting System in 1967, were as follows: contestants were to submit lyrics about (1) seasonal flowers; (2) subjects that promote "healthy and cheerful" emotions; (3) folklore or national holidays; (4) words that encourage the soldiers in Vietnam; or (5) children's plays. ${ }^{61}$

In addition to public music events, contests, and radio programs, loudspeakers served as another important medium to distribute songs. Throughout the 1960s and 1970s, before household radios became widespread, the government installed loudspeakers across the country and utilized them as the primary means of communication, especially in the countryside. ${ }^{62}$ Records show that kŏnchŏn kungmin kayo streamed through these loudspeakers throughout the 1960s. For example, at government offices, these songs were played for 30 minutes in the morning, during lunch time, and before the end of the day. ${ }^{63} \mathrm{~A}$ portrayal of the presidential election campaign of 1967 describes that one of the most prominent kŏnchŏn kungmin kayo, entitled "Ch'al sarabose" [Let's live well], gushed out of some 170 loudspeakers. ${ }^{64}$

Despite the nationwide effort, it seems that the songs did not gain much popularity in the 1960s because of their overt propagandistic character. ${ }^{65}$ However, these types of moral songs continued to be written and distributed under the auspices of the government and permeated the daily lives of Koreans for nearly two more decades. Perhaps the best-known of all kŏnchŏn kungmin kayo songs throughout these years is "Saemaŭl Norae" [New village song]. Its lyrics were written by Park Chung-Hee himself and set to music by his daughter, Park Geun-ryeong (the younger sister of Korea’s 18th president, Park Geun-

\footnotetext{
${ }^{57}$ These composers included Hŭng-ryŏl Lee, Sŏng-t'ae Kim, Tong-chin Kim, and Tae-hyŏn Kim, who all normally composed art music, not popular music. Chang-min Song, "Pakchŏnghŭi chŏnggwŏnŭi kungmin'gaech'angundonggwa

han'gukch'angjakkagok,” Kaeksŏk [Auditorium], December 1, 2016, http://auditorium.kr/2016/12/박정희-정권의-

국민개창운동과-한국창작가곡.

${ }^{58}$ Kyunghyang Shinmun, October 15, 1962, 6; Dong-a Ilbo, October 24, 1962, 8; ibid., November 29, $1962,8$.

59 "Da hamgge noraerul" [Let's all sing together] was the name of another singing campaign launched in 1969. Dong-a Ilbo, July 31, 1969, 5.

${ }^{60}$ Such an announcement was made, for example, in Kyunghyang Shinmun, September 14, 1966, 5.

${ }^{61}$ Dong-a Ilbo, July 6, 1967, 5.

${ }^{62}$ A report from 1962 shows that there were 319,357 loudspeakers across South Korea by that year. Kyunghyang Shinmun, July 19, 1962, 2.

${ }^{63}$ Maeil Business Newspaper, May 27, 1967, 1.

${ }^{64}$ Kyunghyang Shinmun, April 29, 1967, 7.

${ }^{65}$ Dong-a Ilbo, September 7, 1962, 5. The music critic Park Yong-ku wrote that the songs failed to appeal to the masses because their lyrics were too far from public sentiments. Dong-a Ilbo, September 27, 1962, 4.
} 
hye), who had studied music at college.

This edifying song was the representative song of the Saemaŭl Undong, or the New Village Movement, that began in 1970 with the goal to modernize the rural areas of South Korea. ${ }^{66}$ The movement, which lasted about ten years, until shortly after Park's sudden death in October 1979, is today considered by some a central force that led to the rapid economic development of South Korea. At the heart of the movement was the idea that every citizen took charge of the cleanliness and development of their own neighborhood, which would eventually lead to the improvement of the entire country. Literature scholar Youngju Ryu describes the nature of the campaign aptly:

Thus, when Korean citizens got up at the crack of dawn and began their day by sweeping the sidewalk to the beat of a Saemaul song playing over the neighborhood public address system, a song whose words were written by none other than President Park himself, they were not simply keeping their communal environment neat. Through these individual practices of diligence and cooperation, they were actually bettering themselves spiritually and bringing about a brighter future for their nation. ${ }^{67}$

Because both individual motivation and cooperation among villagers were key to the success of the movement, a song that everyone knew and sang together proved to be a particularly effective tool. In other words, a Saemaŭlsong was essentially a modern-day labor song.

Saemaŭ I Norae [New village song]

The morning bell has rung, a new morning has broken

Let's all wake up and build a new village.

Refrain:

My village, a good place to live.

Let's build it on our own.

Let's demolish thatched houses, widen village roads, make green hills, and care for them providently.

Let's help each other and by the sweat of our brow, strive to grow income and make our village a rich one.

Let's steadfastly battle to work and work to battle and build a new country.
새벽종이 울렸네 새아침이 밝았네

너도나도 일어나 새마을을 가꾸세

후렴

살기좋은 내마을, 우리힘으로 만드세

초가집도 없애고 마을길도 넓히고 푸른동산 만들어 알뜰살뜰 다듬세

서로서로 도와서 땀흘려서 일하고 소득증대 힘써서 부자마을 만드세

As with other kŏnchŏn kungmin kayo, the song was distributed strategically. It was recorded on cassette tapes and circulated, along with other national songs, among the public; it was also included the government-published music textbook by $1973 .{ }^{68}$ As a result, more than any other songs, "Saemaŭ 1 Norae" became the ultimate song that was memorized, sung, and performed by all Koreans throughout the 1970s. Their soundscape was practically inundated with kŏnchŏn kungmin kayo and the messages of hard work

${ }^{66}$ See In-Joung Whang, Management of Rural Change in Korea: The Saemaul Undong (Seoul: Seoul National University Press, 1981).

${ }^{67}$ Youngju Ryu, "Introduction," Cultures of Yusin, 9-10.

${ }^{68}$ Kyunghyang Shinmun April 17, 1978, 8; Kyunghyang Shinmun, July 8, 1972, 7. 
and striving for a better future. Even about 50 years later, the memory of "Saemaŭl Norae"seems palpable to people who lived through that time:

... The morning bell has rung, a new morning has broken / Let's all wake up and build a new village [first part of the Saemaŭl Norae] . . . Most of Korea's middle-aged and elderly men and women remember waking up to the resounding sound of Saemaŭl Norae. ${ }^{69}$

Another journalist recalls that, throughout the 1970s, Koreans began each day with the sound of "The morning bell has rung" and those in any leadership positions, whether finance, journalism, religion, or education, were obliged to sing "Saemaŭl Norae" during their training according to the Saemaŭl system. ${ }^{70}$ Elderly Koreans, including my own parents and relatives who were students in the 1960s and 1970s, attest that the song was played at schools, various public events, on the streets, and even at some bars. Community gatherings involved communal singing of "Saemaŭl Norae" along with other kŏnchŏn kungmin kayo songs, a practice fostered through municipal singing festivals. ${ }^{71}$ The ubiquity of "Saemaŭ 1 Norae" is also recorded in many Korean novels set in those years. Excerpts of some of novels read as follows:

... But that morning, when the First Lady was supposed to visit the town, Bongdal woke up to the sound of the song Morning bell has rung, a new morning has broken / Let's all wake up, which came out of the village speaker. . (Ki-jong Kim, "Babo Huh Bongdal” [Huh Bongdal the simpleton] $)^{72}$

As we walked into the school, standing at the gate were the proctor and students of the discipline class. The proctor summoned students and inspected, using a plastic ruler, that their skirts weren't above their knees, that their hair didn't grow more than one centimeter below their ears, or that the hair was cut in any fancy way. Those who passed the inspection then quietly tiptoed along the playground, keeping to the left, to get to their classrooms. Morning bell has rung was streaming from the speaker, just like any other day. It was a song that we heard so many times that none of us thought of it as a song. Yet there it went again. Morning bell has rung. . . (Chi-yong Kong, "Kwanggi üi yoksa" [Chronicle of an insanity]). ${ }^{73}$

While Saemaŭl Norae permeated the lives of Korean people, the 1980s also saw a new practice, namely popular music albums being capped off with a kŏnchŏn kungmin kayo. It was the result of an obligatory policy impelled in 1979 by Kongyŏn Yulli Wiwonhhoe [Ethics Committee of Public Performance], an official arm of the government of Chun Doo-Hwan, Park's successor who pressed on many of his economic and social policies, under of the proposition of "effective execution of social

\footnotetext{
${ }^{69}$ Seung-kyu Jang, “Saemaŭl Undong still lives,” Hankuk Kyungje Mehgujin [Korean Economics Magazine], August 26, 2008, accessed October 14, 2019, http://magazine.hankyung.com/apps/news?popup $=0 \&$ nid $=21 \&$ nkey $=2008082600665000021 \&$ mode $=$ sub view.

${ }^{70}$ Maeil Business Newspaper, December 27, 1999, 57.

${ }^{71}$ Records of such gatherings come from numerous newspaper articles throughout the 1970 s. Some of these include: Dong- $a$ Ilbo, March 16, 1972, 8; Kyunghyang Shinmun, March 10, 1975, 7; Kyunghyang Shinmun, May 6, 1976, 6.

72 This children's story was published in Ki-jong Kim, Hae rul Samk'in Aidul [Children who swallow the sun] (P'aju-si: Ch'angbi, 2004).

${ }^{73}$ This passage comes from Chi-yong Kong's "Kwaggi ŭi yoksa” [Chronicle of an insanity], published in a collection of short stories: Chonjae nun Nunmul ul Hullinda [An existence shed tears] (Seoul: Ch'angjak kwa Pip'yongsa, 1999).
} 
purification." 74 This rule was imposed regardless of the genre of an album, whether rock or ballad, and the addition of songs such as "Jokuk Changa" [Song in praise of our country], "Sijange gamyon" [At a market], or "Sŏro minnŭn uri maŭm" [Our trusting hearts] as the final track often resulted in a bizarre listening experience. Despite the musicians' grievances toward this practice that utterly detracted from the coherence or overall ambiance of their recordings, the custom as well as kŏnchŏn kungmin kayo itself grew increasingly familiar to Korean people. By the 1980s, some kŏnchŏn kungmin kayo had evolved to sound less like propaganda music; a few of them even became some of the public's most loved songs. For instance, Jung Su-ra's A Taehanmin'guk [Ah, Korea] (1983; composed by Kim Chaeil, lyrics by Pak Kŏnho), a song that blatantly eulogizes Korea with words such as "ah, my country, I will forever love," topped the Korean music charts for several weeks. The political and economic contexts of the popularity of such kŏnchŏn kungmin kayo songs in the 1980s are dynamic and intricate, but that is for a different essay. $^{75}$

\section{Conclusion}

Throughout the Park Chung-Hee era, Korea as a nation was preoccupied with the mission of catching up on the lost years of modernization. Park sought to achieve this goal by uplifting the collective national spirit, and as we have seen, kŏnchŏn kungmin kayo-"healthy national popular songs"—was his preferred tool to promote optimism and industriousness among the Korean people. Kŏnchŏn kungmin kayo was composed by both civilians and well-known composers; it was distributed to the general public through strategically implemented campaigns beginning in 1961, as soon as Park rose to power through a military coup. This essay has explored the kŏnchŏn kungmin kayo of the 1960s to show that the Park government's endeavors to regulate Korea's popular music culture and to shape the public's mind began mostly with efforts to encourage civilian participation before they turned into the forced communal rituals and proscription of popular music of the Yusin period. Perhaps the significance of such exposition is that the practice of kŏnchŏn kungmin kayo under Park, at least during its initial years, may have been a less gloomy or repulsive experience than how it is recounted today to those who lived during that time, who did not anticipate the regulations to become a full-blown crackdown years later. That may also mean that the messages of morality, national rebuilding, and striving for betterment carried in kŏnchŏn kungmin kayo could have been accepted by the Koreans of the time, to whom poverty was a fact of life, rather readily, as suggested in the surfacing of the notions of autonomy and Chuch'esŏng in the mid-1960s. Unfortunately, whatever good was gained during that time was obliterated by the despotic turn of the regime in the early 1970 s.

In a final note, it is worthwhile to note that the Park Chung-Hee era also saw a great stride in terms of Korea's restoration of its traditional culture, which is undoubtedly linked to the regime's objective of achieving a collective national pride. It was during this period that several universities started Korean studies or Asian studies institutes and the Minister of Culture and Education launched a separate unit

\footnotetext{
${ }^{74}$ Park Chung-Hee's prime minister Choi Kyu-Hah served in the office of president for eight months after Park's assassination, but he lacked any political line and was a lame duck throughout his incumbency. Chun Doo Hwan's government formed in November 1980 an official government arm, Sahoe fŏnghwa Wiwŏnhoe [The committee of social purification], to carry out this task.

${ }^{75}$ Yŏng-mi Yi, Han'guk taejung kayosa [History of Korean Popular Music] (Seoul: Minsogwŏn, 2006).
} 
dedicated to the discovery and archiving of traditional literature from the pre-colonial period. ${ }^{76}$ Also, in early 1966, Yegrin, an ensemble that had begun in 1963 to stage Korean traditional music, dance, and theater but soon disintegrated for financial reasons, was revived with the support of the politician Kim Jong-Pil, the right arm of President Park. ${ }^{77}$ Nationwide contests of traditional culture and customs were held, more traditional theatrical plays were staged than ever before, and old palaces and temples were revitalized throughout the late 1960s and 1970s. ${ }^{78}$ In all of these measures, Park's bias toward "pure" art and cultural tradition is evident. After all, that partiality was the ideological underpinning for the majority of his cultural policies, kŏnchŏn kungmin kayo being one of the firsthand proofs of such an ideal.

\section{Bibliography}

\section{Newspaper sources}

Dong-a Ilbo (1954-1972)

Kyunghyang Shinmun (1953-1978)

Maeil Business Newspaper (1966-1999)

\section{Online sources}

Anonymous. "South Korea Banning 'Decadent' Foreign Music, Including Many Protest Songs.”

The New York Times. December 28, 1975. Accessed October 14, 2019. https://www.nytimes.com/1975/12/28/archives/south-korea-banning-decadent-foreign-musicincluding-many-protest.html.

Song, Chang-min. "Pakchŏnghŭi Chŏnggwŏnŭi Kungmin'gaech'angundonggwa Han'gukch'angjakkagok" [Park Chung-Hee government's national singing campaigns and Korea's creative art songs]. Kaeksŏk [Auditorium]. December 1, 2016. Accessed October 14, 2019. http://auditorium.kr/2016/12/박정희정권의-국민개창운동과-한국창작가곡.

Chick, Stevie. "Shin Joong Hyun: South Korea's Psychedelic Mimic Turned Master." The Guardian. September 15, 2011. Accessed October 14, 2019. https://www.theguardian.com/music/2011/sep/15/shin-joong-hyun-korean-psychedelic.

Institute for Military History. “Betŭnam chŏnjeng iran?: Che sach’a pabyŏng (9 sadan) ŭn ŏddŏke iruŏ chyŏ tna?" [What was the Vietnam War: How did the 4th dispatch (the 9th Infantry Division) happen?]. Accessed October 14, 2019. http://medcmd.mil.kr/user/imhc/download/vetnam/V14.pdf.

National Archives of Korea. "Kungmin kayo dangsŏnja pyochang" [Awarding winners of kungmin kayo]. Accessed October 14, 2019. http://theme.archives.go.kr/viewer/common/archWebViewer.do?bsid=200200004259\&dsid=000000 $\underline{000005 \& g u b u n=\text { search. }}$.

National Archives of Korea. "Norae ŭi meari undong kyehwek" [Plans for the Echoes of Songs campaign]. Accessed October 14, 2019.

\footnotetext{
${ }^{76}$ Plans for those programs were announced in Dong-a Ilbo, September 28, 1968, 6. Many of the programs launched between 1968 and 1969. Kyunghyang Shinmun, December 15, 1969, 5.

${ }_{77}^{7 y}$ Kynghyang Shinmun, February 26, 1963, 8; Dong-a Ilbo, February 22, 1966, 5.

${ }^{78}$ The national museum was built between 1966 and 1969 inside the Gyeongbokgung Palace, the main palace of the Chosŏn Dynasty. Maeil Business Newspaper, November 21, 1966, 2.
} 
http://theme.archives.go.kr/viewer/common/archWebViewer.do?bsid $=200300838913 \& d s i d=000000$ 000031\&gubun=search.

Presidential Archives. "1964 nyŏn taet'ongnyŏng yŏndugyosŏ” [The State of the National Message, 1964]. Accessed October 14, 2019. http://pa.go.kr/research/contents/speech/index.jsp.

Jang, Seung-kyu. "Saemaŭl Undong ŭn saraidda” [ Saemaŭ IMovement still lives]. Hankuk Kyungje Mehgujin [Korean Economics Magazine]. August 26, 2008. Accessed October 14, 2019. http://magazine.hankyung.com/apps/news?popup $=0 \&$ nid $=21 \&$ nkey $=2008082600665000021$ \&mode=sub_view.

\section{Books and articles}

Armstrong, Charles K. The Koreas. New York: Routledge, 2014. https://doi.org/10.4324/9780203079652.

Byeong-cheon, Lee, ed. Developmental Dictatorship and The Park Chung-Hee Era: The Shaping of Modernity in the Republic of Korea. Translated by Eungsoo Kim and Jaehyun Cho. Paramus, NJ: Homa \& Sekey Books, 2003.

Baldwin, Frank. "America's Rented Troops: South Koreans in Vietnam." Bulletin of Concerned Asian Scholars 7, no. 4 (1975): 33-40. https://doi.org/10.1080/14672715.1975.10406389.

Cha, Victor. The Impossible State: North Korea, Past and Future. New York: Ecco, 2012.

Chang, Hyun Kyong Hannah. "Exilic Suffering: Music, Nation, and Protestantism in Cold War South Korea," Music and Politics 8, no. 1 (2014). http://dx.doi.org/10.3998/mp.9460447.0008.105.

Choi, Lyong. "Human Rights, Popular Protest, and Jimmy Carter's Plan to Withdraw US Troops from South Korea." Diplomatic History41, no. 5 (2017): 933-958. https://doi.org/10.1093/dh/dhx030.

Cumings, Bruce. Korea's Place in the Sun: A Modern History. New York: W. W. Norton, 2005.

Kim, Byung-Kook. "Introduction: The Case for Political History." In The Park Chung Hee Era: The Transformation of South Korea, edited by Byung-Kook Kim and Ezra F. Vogel, 1-34.

Cambridge, MA: Harvard University Press, 2011. https://doi.org/10.4159/harvard.9780674061064.intro.

Kim, Eun-kyoung. "Yusin Cheje ŭ i Ŭmak Tongje Yangsange Kwanhan Yŏnku: Kŏ myŏl Mekŏnijŭ m kwa Kŏmjikok ŭl Chungsim ŭ ro" [Study on an aspect of music regulation under the Yusin system: centered on mechanisms of ban and banned songs]. Journal of Democracy and Human Rights 11, no. 2 (2011): 67-96.

Kim, Ki-jŏng. “Babo Hŏh Bongdal” [Huh Bongdal the simpleton]. In Hae rŭl Samk'in Aidŭl [Children who swallow the sun]. P'aju-si: Ch'angbi, 2004.

Kim, Ŭn-gyŏng. “Pak Chŏng-hŭ i Ch'eje ŭi Ŭmak Chŏngch'aek e Kwanhan Bipanjŏk Yŏnkü' [Critical study of music policies of the Park Chung-Hee regime]. Journal of Korean Political and Diplomatic History 35, no. 1 (2013): 41-70. https://doi.org/10.18206/kapdh.35.1.201308.41.

Kong, Chi-yŏng. "Kwaggi ŭi Yŏksa” [Chronicle of an insanity]. In Chonjae nŭn Nunmulŭl Hŭllinda [An existence shed tears]. Seoul: Ch'angjak kwa Pip'yŏngsa, 1999.

Lee, Jin-ah. “1960nyeondae Kayo Jŏnghwa Undong kwa Kŏnchŏn Kungmin Kayo Changchul” [Song purification movement and the making of kŏnchŏn kungmin kayo during the 1960s]. The Korean Sociological Association 6 (2009): 391-408.

Lee, Jung-Hoon. “Normalization of Relations with Japan: Toward a New Partnership.” In The Park Chung Hee Era: The Transformation of South Korea, edited by Byung-Kook Kim and Ezra F. Vogel, 430-456. Cambridge, MA: Harvard University Press, 2011. 
Lee, Min Yong. “The Vietnam War: South Korea's Search for National Security.” In The Park Chung Hee Era: The Transformation of South Korea, edited by Byung-Kook Kim and Ezra F. Vogel, 403-429. Cambridge, MA: Harvard University Press, 2011.

Lee, Seung-Ah. "Decolonizing Korean Popular Music: The 'Japanese Color' Dispute over Trot.” Popular Music and Society 40, no. 1 (2017): 102-110. https://doi.org/10.1080/03007766.2016.1230694.

Moon, Seungsook. "The Cultural Politics of Remembering Park Chung Hee.” The Asia-Pacific Journal 19, no. 5 (2009). https://apjjf.org/-Seungsook-Moon/3140/article.html.

Mun, Ok-pae. Han'guk Kŭmjigok ŭi Sahoesa [Social history of banned songs in Korea]. Seoul: Yesol, 2004.

Oberdorfer, Don, and Robert Carlin. The Two Koreas: A Contemporary History. New York: Basic Books, 2014.

Park, Sang Mi. "The Paradox of Postcolonial Korean Nationalism: State-Sponsored Cultural Policy in South Korea, 1965-Present.” The Journal of Korean Studies 15, no. 1 (2010), 67-93.

Robinson, Michael. "Broadcasting, Cultural Hegemony, and Colonial Modernity, 1924-1945.”

In Colonial Modernity in Korea, edited by Shin Gi-Wook and Michael Robinson, 52-69. Cambridge, MA: Harvard University Asia Center, 1999.

Ryu, Youngju, ed. Cultures of Yusin: South Korea in the 1970s. Ann Arbor: University of Michigan Press, 2018. https://doi.org/10.3998/mpub.9709426.

Song, Hwa-suk. “Pahk Ch’ŏng-Hŭ i ŭi kukka kŭndehwa pŭrojektŭ wa ŭmak” [Park Chung-Hee's national modernization project and music]. Unak-sa Yõnku [Music History Studies] 1 (2012): 167-204.

Whang, In-Joung. Management of Rural Change in Korea: The Saemaŭ1 Undong. Seoul: Seoul National University Press, 1981.

Woo-Cumings, Meredith. Race to the Swift: State and Finance in Korean Industrialization. New York: Columbia University Press, 1991.

Yi, Pyŏng-ch‘ŏn, ed. Kaebal Tokchae wa Pak Chŏng-hŭi Sidae: Uri Sidae ŭi Chŏngch i Kyŏngjejŏk Kiwŏn [Development dictatorship and the Park Chung-Hee era: the political and economic origins of our time]. Kyŏnggi-do P'aju: Ch'angbi, 2003.

Yi, Kyu-ho. "Chuch'esŏng." Kitokkyo Sasang [Christian ideology] 9, no. 8 (1965): 95.

Yi, Yŏng-mi. Han'guk Taejung Kayosa [History of Korean Popular Music]. Seoul: Minsogwŏn, 2006.

Yim, Dobin. "Pak Chŏng-hŭi Chŏngbu Kukchŏng Unyŏng ŭi Mokpyo mit Panghyang [Park Chung-Hee government's governance objectives and directions].” In Taehan Min'guk Yǒktae Chŏngbu Chuyo Chŏngch'aek kwa Kukchŏng Unyŏng: 2. Pak Chŏng-hŭi Chŏngbu [Chronology of key policies and governance of the governments of the Republic of Korea: vol. 2. Park Chung-Hee government], edited by Han'guk Haengjŏng Yŏn'guwŏn [Korea Institute of Public Administration], 36-67. Seoul: Tosŏ Ch'ulp'an Taeyŏng Munhwasa, 2014. 